\title{
FIRST ISOLATION OF VIBRIO PROBIOTICUS FROM THE GUT OF PORTUNUS PELAGICUS (LINNAEUS, 1758) AND ITS PROBIOTIC COMPETENCY AGAINST SHELLFISH PATHOGENS
}

\author{
Allah Dad Talpur ${ }^{\text {ab* }}$, Mhd Ikhwanuddin ${ }^{\mathrm{b}}$ \\ ${ }^{a}$ Department of Fisheries, Government of Sindh, Pakistan. \\ ${ }^{\mathrm{b}}$ Institute of Tropical Aquaculture, Universiti Malaysia Terengganu, 21030, Kuala Terengganu, Malaysia. \\ *Corresponding author: mrtalpur@yahoo.com
}

\begin{abstract}
In this study, the Vibrio probioticus was isolated from the gut of female Portunus pleagicus, identified through 16S rDNA gene sequencing, and was evaluated for its probiotic features. The probiont was tested in coculture assay at various concentrations against three target shellfish pathogens including $V$. harveyi, $V$. parahaemolyticus and Pseudoalteromonas piscicida. In a co-culture assay it was apparent that the V. probioticus had shown to outcompete the growth of tested pathogenic bacteria due to its antibacteriocin properties. Different ratios produced different effect on tested pathogens, however, the highest ratio (pathogen:probiont) was more effective in suppressing the pathogen. A maximum inhibition growth was recorded for $V$. harveyi and P. piscicida. The probionts could further be tested in vivo culture environment to understand the effectiveness in microbial control of $P$. pelagicus larviculture and other aquaculture species.
\end{abstract}

Keywords: Vibrio probioticus; 16S rDNA sequencing; Antibacteriocin; Probiont; Larviculture

\section{Introduction}

The intensive rearing conditions for marine fish larvae provide an environment favourable for pathogenic bacteria [1] that may cause microbial problems and high larval mortality. To overcome of the microbial problems encountered in the intensive rearing of marine larvae, controlled colonization of the bacterial flora can be achieved by replacing with probiotic bacteria [2]. Most important bacterial pathogens of fish include the gram-negative species, which cause the infections and result high mortality in fish hatcheries. At present, owing to disease and high mortalities in hatchery operations, microbial infections are generally cured either through chemotherapeutic treatment of antibiotics or disinfectants. However, frequent use of antibiotics has led to drug-resistant bacteria that are difficult to control and exterminate $[3,4,5,6]$. Probiotics can be the alternative, which may reduce the frequency of microbial proliferation or diminish the sternness of disease eruptions. Probiotics are defined as "live microorganisms, which when administered in sufficient quantity bestow a health benefit to the host" [7]. When selecting probiotic microorganisms with beneficial health effects for the host, many criteria have to be met. For example, probiotic species selection requires cautious testing of potential species benefits both in vitro and in vivo. The mechanisms used include the production of inhibitory substances against pathogens, a benefit effect to the host; moreover, species of bacteria require careful screening and selection before incorporation as a probiotic.
The aim of the current study was to characterize the probiotic properties of $V$. probioticus isolated from the gut of blue swimmer crab, $P$. pelagicus by examining antibacterial properties against three shellfish pathogens (previously isolated from $P$. pelagicus).

\section{Materials and Methods \\ Study site and sampling site}

The present study was conducted in the laboratory of the Institute of Tropical Aquaculture, Universiti Malaysia Terengganu (UMT), Malaysia. Crab sample was collected from Strait of Tebrau, Johor, Malaysia, $\left(1^{\circ} 22^{\prime} \mathrm{N}\right.$ and $\left.103^{\circ} 38^{\prime} \mathrm{E}\right)$ with 188.4 gm of body weight (BW), $13.4 \mathrm{~cm}$ carapace width $(\mathrm{CW})$ and $6.3 \mathrm{~cm}$ carapace length. The collected sample was transferred to 40 litres round polythene tanks filled with sea water from sampling site and equipped with aeration along with other crab samples. Salinity at site was measured between 31 33 ppt with Refracto-meter (Reichert Tech). To avoid contamination, the sample was kept in same sea water until it dissected for microbes study.

\section{Removal of the gut and bacteria culture}

Prior to segregation of the gut, crab specimen was bathed in $10 \%$ formalin for 20 minutes. Subsequently, it was again washed with fresh tap water for 5 minutes and finally washed with sterilised de-mineralised water in order to get rid of surface micro flora if attached to it. Sterilised dissecting materials were used for dissecting purpose. 
Aseptically crab specimen was dissected, the whole gut (foregut and hindgut) was removed and washed two times with sterilised de-mineralised water then pulverised with pestle and mortar vigilantly and mixed with sterilised sea water to prepare the inoculums.

Bacteria isolation were carried out by 10 fold serial dilution up $10^{-5}$. A volume $0.1 \mathrm{ml}$ of inoculums was plated in selective culture media Thiosulphate Citrate Bile Salts (TCBS, Difco, USA) for the bacterial growth. Culture media was prepared in sterilised sea water $(31 \pm 2 \mathrm{ppt})$. Inoculated plates were incubated at $37^{\circ} \mathrm{C}$ for 24 hours. A pure culture was obtained by repeated streaking method.

\section{Total genomic DNA extraction}

Total genomic DNA of sample was extracted using Wizard ${ }^{\circ}$ Genomic DNA Purification Kit (Promega, USA) following the manufacturer's instruction. Briefly, $1 \mathrm{ml}$ of overnight culture was centrifuged for 2 minutes at 13,000 rpm. The cells were then suspended in $480 \mu \mathrm{l}$ of $50 \mathrm{mM}$ EDTA and $120 \mu \mathrm{l}$ of lytic enzyme before incubation at $37^{\circ} \mathrm{C}$ for 60 minutes. The mixtures were then centrifuged for 2 minutes at $13,000 \mathrm{rpm}$ and the supernatant was removed. Nuclei Lysis Solution $600 \mu \mathrm{l}$ was added to the pellet and mixed gently by pipetting. The mixture was then incubated for 5 minutes at $80{ }^{\circ} \mathrm{C}$ and left over to cool down at room temperature. RNase Solution $3 \mu \mathrm{l}$ was added to the mixture, and incubated at $37{ }^{\circ} \mathrm{C}$ for 30 minutes and subsequently cooled at room temperature. Afterwards $200 \mu \mathrm{l}$ of Protein Precipitation Solution added to mixture, vortexed and incubated on ice for 5 minutes, followed by centrifugation at $13,000 \mathrm{rpm}$ for 3 minutes and supernatant was transferred to a clean tube containing $600 \mu \mathrm{l}$ of room temperature isopropanol and mixed properly. The mixture was centrifuged for 2 minutes at $13,000 \mathrm{rpm}$, and the supernatant decanted, and then $600 \mu \mathrm{l}$ of $70 \%$ ethanol (room temperature) was added, mixed, and centrifuged for 2 minutes at 13,000 rpm. The ethanol subsequently aspirated and the pellet air-dried for 10 15 minutes. Following the rehydration of DNA pellet in $100 \mu \mathrm{l}$ of Rehydration Solution for 1 hour at $65^{\circ} \mathrm{C}$ or overnight at $4{ }^{\circ} \mathrm{C}$.

\section{Polymerase Chain Reaction (PCR) amplification of $16 \mathrm{~S}$ rDNA}

The 16S ribosomal DNA was amplified by PCR using bacterial universal primers 27F (5' AGAGTTTGATCCTGGCTCAG-3') and 1492R-(5'GGTTACCTTGTTACGACTT-3'). Briefly, the PCR reaction was performed in a Bio Thermal cycler (BioRad, USA), with an initial denaturing step at $95{ }^{\circ} \mathrm{C}$ for 5 minutes, followed by 30 cycles of $95{ }^{\circ} \mathrm{C}$ for 30 seconds, $50{ }^{\circ} \mathrm{C}$ for $30 \mathrm{sec}$, and $72{ }^{\circ} \mathrm{C}$ for 1 minute, and ended with a final extension step of $72{ }^{\circ} \mathrm{C}$ for 15 minutes. The PCR product was electrophoresesed in $1 \%$ molecular grade agarose gel (Aventis)) stained with $1 \mu \mathrm{g} / \mathrm{ml}$ of ethidium bromide and was then visualised using Alpha Imager gel documentation system (Alpha Innotech, UK). Sequences obtained were analysed and compared with sequences from GenBank, using BLAST NCBI citation (http://blast.ncbi.nlm.nih.gov).

\section{Morphological, physiological and biochemical characteristics of isolate \\ Morphological, physiological and} biochemical features were carried out using standard procedures and BBL Crystal Kit (Becton, Dickinson and company, USA), was also used.

\section{Target pathogen}

Three shellfish pathogens isolated from the gut of female $P$. pelagicus and were identified as $V$. harveyi, $V$. parahaemolyticus and $P$. piscicida [8] were used as the target pathogens.

\section{Co-culture antagonistic assay}

The co-culture method was performed according to Rahman et al. [9] to observe the antagonistic potential of the probiont growing with the target pathogens including $V$. harveyi, $V$. parahaemolyticus and $P$. piscicida. Bacterial population of $10^{6}$ cells measured to optical density $\left(\mathrm{OD}_{630 \mathrm{~nm}}\right)$ was used as standard ratio for the experiment. The culture broth of the $V$. probioticus and the target organisms were inoculated separately into $50 \mathrm{ml}$ marine broth (Difco) prepared in natural sea water. The different combinations of bacterial population at ratios 1:1, 1:2, 1:3 and 1:4 were obtained by mixing the culture of target pathogens and the $V$. probioticus bacteria respectively. The cocultures was prepared in duplicates and incubated at $37{ }^{\circ} \mathrm{C}$, samples were serially diluted up to $10^{-5}$ and $0.1 \mathrm{ml}$ from each co-culture was plated daily in TCBS agar and marine agar up to four days for vibrios and $P$. piscicida enumeration respectively.

\section{Statistical analysis of data}

Comparison followed by ANOVA $(\mathrm{p}<0.05)$, treatment and inoculum concentration being the factors. Post hoc comparisons were compared using LSD test and Tukey's test. All statistics were performed using SPSS version 16 for Microsoft Windows.

Results

Segregated foregut and hindgut of $P$. pelagicus is shown in Figure. 1 respectively. 

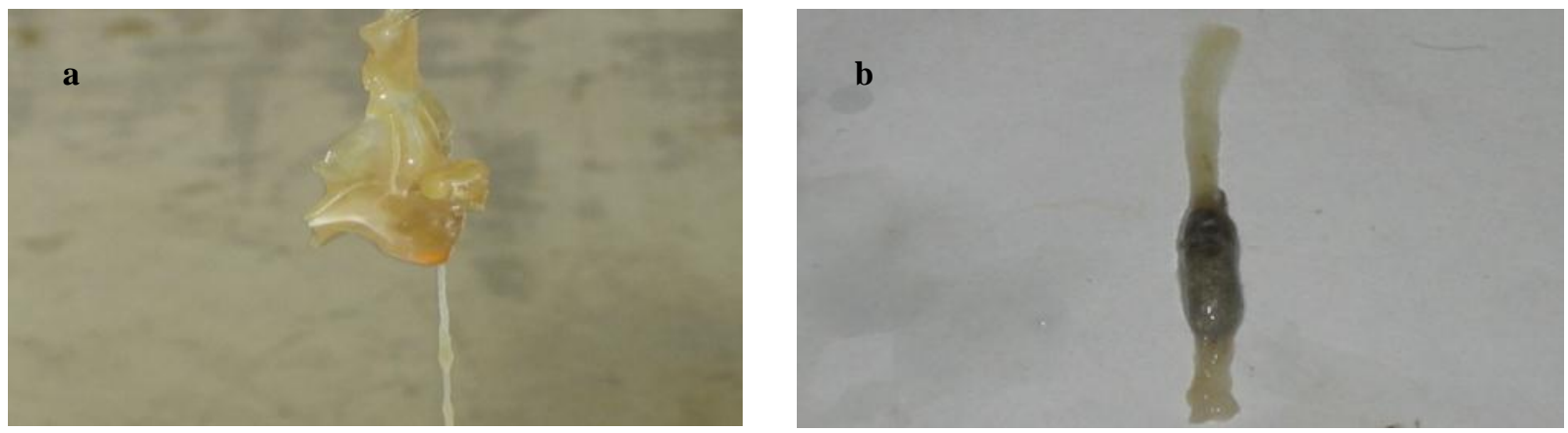

Figure1. Images show the foregut (a) and hindgut (b) of blue swimming crab, P. pelagicus.

\section{Morphological, physiological and biochemical features of $V$. probioticus}

Cells of $V$. probioticus strain appeared bright yellow, smooth-rounded colonies of $>6 \mathrm{~mm}$ diameter on TCBS agar at $37^{\circ} \mathrm{C}$ after 48 hours. Physiological and biochemical characteristics of $V$. probioticus are illustrated in Table 1.

\section{Identification of $\boldsymbol{V}$. probioticus}

Sequences obtained through $16 \mathrm{~S}$ rDNA were analyzed and compared with sequences from data base GenBank using BLAST (megablast) National Center for Biotechnology Information (NCBI, USA) online data bank citation (http://blast.ncbi.nlm.nih.gov). Result obtained from GenBank isolate as $V$. probioticus (Accession No. AJ345063.1).

\section{Co- culture antagonism assay}

The $V$. probioticus isolate which demonstrated maximum reduction of pathogens count following each day, preferably at a lower ratio were considered to be the most potential candidate. As a result, the $V$. probioticus isolate demonstrated the antagonistic activity against all pathogens. A maximum inhibition growth was recorded for $V$. harveyi and P. piscicida (Fig. 2 and 3), whereas the isolate showed moderate activity against the target $V$. parahaemolyticus (Fig. 4).

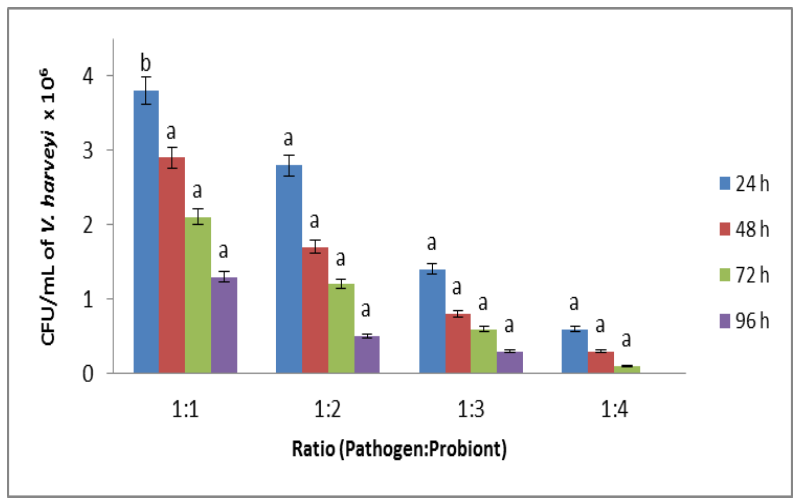

Figure 2. Co-culture experiments using $V$. harveyi as a target pathogen and probiotic bacteria at different population ratios (Pathogen: Probiont). The result is expressed as a mean of duplicate observations in terms of Vibrio count on TCBS agar for four-day long antagonistic activity of the probiont. Means with different letters on bars were not significantly different from control $(p>0.05)$
On the day four, only $V$. harveyi pathogens was eliminated by tested $V$. probioticus. Different ratios had shown different effect on target pathogens and higher concentrations of probiont showed better result compared to lower concentration. The concentration ratio at $1: 4$ totally eliminated $V$. harveyi after 96 hours (Fig 2). In general all pathogens were affected by the antibacterial activity of the tested V. probioticus.

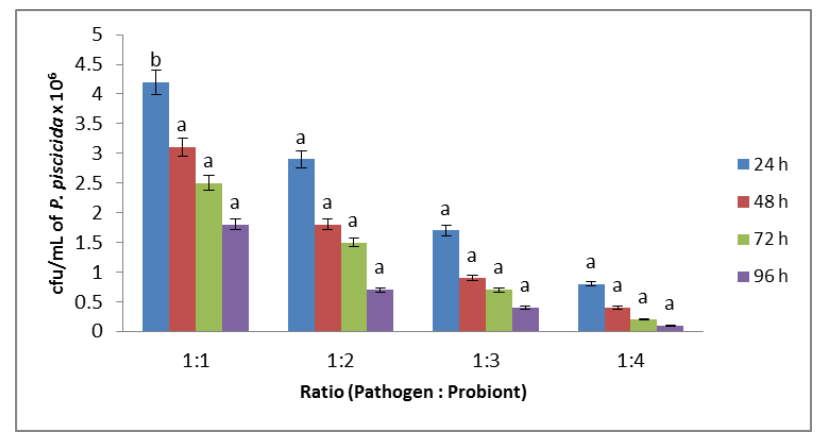

Figure 3. Co-culture experiments using $P$. piscicida as a target pathogen and probiotic bacteria at different population ratios (Pathogen: Probiont). The result is expressed as a mean of duplicate observations in terms of $p$. piscicida count on marine agar for four-day long antagonistic activity of the probiont. Means with different letters on bars were not significantly different from control $(p>0.05)$.

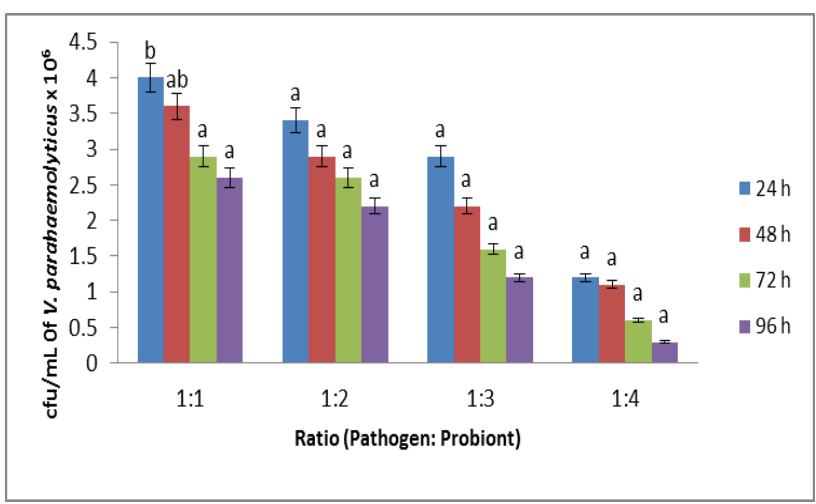

Figure 4. Co-culture experiments using $V$. parahaemolyticus as a target pathogen and probiotic bacteria at different population ratios (Pathogen: Probiont). The result is expressed as a mean of duplicate observations in terms of $V$. parahaemolyticus count on TCBS agar for four-day long antagonistic activity of the probiont. Means with different letters on bars were not significantly different from control $(p>0.05)$. 
Table 1: Physiological and biochemical characteristics of V. probioticus.

\begin{tabular}{|c|c|c|c|}
\hline Characteristics & Results & Characteristics & Results \\
\hline Growth on TCBS & Yellow & Arginine dihydrolase & - \\
\hline Growth in $\mathrm{NaCl}$ & & Amylase production & + \\
\hline $0 \%$ & + & D-serine & - \\
\hline $2 \%$ & + & 2-aminoethanol & - \\
\hline $3 \%$ & + & Fermentation & + \\
\hline $7 \%$ & + & Phenylalanine Deaminase & - \\
\hline $10 \%$ & + & Fermentation to acid & \\
\hline $12 \%$ & - & Glucose & + \\
\hline Growth in sea water & + & Sucrose & + \\
\hline Growth at ${ }^{\circ} \mathrm{C}$ & & Lactose & + \\
\hline $4^{\circ} \mathrm{C}$ & - & Amygdalin & + \\
\hline $25^{\circ} \mathrm{C}$ & + & Utilization of & \\
\hline $35^{\circ} \mathrm{C}$ & + & Citrate & - \\
\hline $42{ }^{\circ} \mathrm{C}$ & + & Glucose & + \\
\hline $55^{\circ} \mathrm{C}$ & - & Lactose & - \\
\hline DL-carnitine & - & Sucrose & + \\
\hline Oxidase & + & Casein & + \\
\hline Catalase & + & Lipid & + \\
\hline Motility & + & Glycine & + \\
\hline Indole & + & L-Arginine & - \\
\hline $\mathrm{H} 2 \mathrm{~S}$ formation & - & L-Tyrosine & + \\
\hline Urease & - & L-Serine & + \\
\hline Inositol & - & Acetate & - \\
\hline Rhamnose & - & Gelatin liquefaction & - \\
\hline Melibiose & - & Glycogen & - \\
\hline L-threonine & - & $\mathrm{N}$-acetyl-D-galactosamine & - \\
\hline Tween 40 & - & D-glucosaminic acid & - \\
\hline Xylitol & - & $\mathrm{NO}_{3}$ reduction & + \\
\hline
\end{tabular}

Note: Abbreviations; - negative, + positive

\section{Discussion}

With the development of commercial-scale aquaculture, application of probiotics in aquaculture is increasing $[4,10]$. During the present study, the growth of pathogenic microbes was controlled by non-pathogenic $V$. probioticus. In co-culture experiments result showed that the inhibitory activity of the $V$. probioticus increased with increasing density of the bacteria. A relatively higher concentration of antagonist (probiont) was required to inhibit the targeted pathogens in the co-culture experiments. The present study demonstrated that the probiotics at higher levels than the pathogens, the degree of inhibition increased with the level of probiont. Therefore, a potential probiotic co-culture must either be supplied on a regular basis or be able to colonise and multiply on or in the host. Hence, it can be suggested that the isolate of $V$. probioticus species, as discovered from the gut of female $P$. pelagicus crab are very considerable in terms of their capability to produce anti-bacterial component, which suppressed or eliminated pathogens.

Antibacterial activity between microorganisms in nature occurs frequently. The antibacterial capabilities due to bacteriocin production of gut Vibrio species bacteria isolated from juvenile and larvae of Japanese flounder (Paralichthys olivaceus) inhibited Pasteurella piscicida growth [11]. In addition, five isolates from the gut of common clownfish (Amphiprion percula) were found to be inhibitory against a wide variety of pathogens, such as Aeromonas hydrophila, $A$. salmonicida, V. harveyi, $V$. anguillarum, $V$. damsela, $V$. alginolyticus and Carnobacterium piscicola [12]. In another study, Carnobacterium bacteria inhibited the $V$. anguillarum in the turbot (Scophthalmus maximus) and author concluded the use of intestinal bacteria with antagonistic activity may be used to reduce the load of Vibrio species in turbot hatcheries [13].

As above mentioned, the target pathogens were influenced by the production of inhibitory compounds by the tested probiont. However, the results of co-culture assay suggest that pathogens were killed or their growth was inhibited as a result of production of antimicrobial substances by the tested probiont. The results of present study was in match with the previously mentioned studies $[12,13]$ that probiont are able to inhibit the growth of pathogens. In cited literature $V$. probioticus also 
known as $V$. hepatarius and can be found in aquatic animals and the marine environment (14). $V$. probioticus isolate/strain when administrated showed high levels of colonisation in the hepatopancreas of Litopenaeus vannamei shrimp, outcompeted, excluded the shrimp pathogen $V$. harveyi, and enhanced the health and weight of shrimps (14). Relating to $P$. pelagicus literature cited do not offer any information on this probiont, therefore, this is first report for isolation and characterisation of this bacteria as probiont from the gut of female $P$. pelagicus.

Probiotic usages offer a very promising alternative to the use of antibiotics in aquaculture. Further study is needed to elucidate the exact mode of action of the observed beneficial effects and to understand the possibilities and limitations of microbial control in aquaculture particularly in hatchery operations.

\section{Reference}

1. Skjermo J, Salvesen I, Øie G, Olsen Y, Vadstein O (1997). Microbially matured water: a technique for selection of a non-opportunistic bacterial flora in water that may improve performance of marine larvae. Aquaculture International 5: 13-28.

2. Makridis P, Fjellheim AJ, Skjermo J, Vadstein O (2000). Colonization of the gut in first feeding turbot by bacterial strains added to the water or bioencapsulated in rotifers. Aquaculture International 8: $367-380$

3. Angulo F (2000). Antimicrobial agents in aquaculture: potential impact on public health. APUA Newsletters 18, 1-4.

4. Balca'zar JL, de Blas I, Ruiz-Zarzuela I, Cunningham D, Vendrell D, Múzquiz JL (2006). The role of probiotics in aquaculture. Veterinary Microbiology 114:173-186.

5. Esiobu N, Armenta L, Ike J (2002). Antibiotic resistance in soil and water environments. International Journal of Environmental Health Research 12:133-144.

6. Nomoto K (2005). Prevention of infections by probiotics. Journal of Bioscience and Bioengineering 100:583-592.
7. Reid G, Sanders ME, Gaskins HR, Gibson GR, Mercenier A, Rastall RA, Roberfroid MB, Rowland I, Cherbut C, Klaenhammer TR (2003). New scientific paradigms for probiotics and prebiotics. Journal of Clinical Gastroenterology 37: $105-118$

8. Talpur AD, Memon AJ, Khan MI, Ikhwanuddin M, M. Danish Daniel M, Abol-Munafi AB (2011). A novel of gut pathogenic bacteria of blue swimming crab Portunus pelagicus (Linnaeus, 1758) and pathogenicity of Vibrio harveyi a transmission agent in larval culture under hatchery conditions. Research Journal of Applied Sciences 6 (2): 116-127.

9. Rahman S, Khan SN, Naser MN, Karim MM (2011). Safety issues of isolated Probiotic natured bacteria from Bangladesh coastal waters for controlling shrimp diseases. Journal of Science Research 3 (3): 659-668.

10. Gatesoupe FJ (2007). Live yeasts in the gut: natural occurrence, dietary introduction, and their effects on fish health and development. Aquaculture 267: 2030 .

11. Sugita H, Okano R, Suzuki Y, Iwai D, Mizukami M, Akiyama N, Matsuura S (2002). Antibacterial abilities of intestinal bacteria from larval and juvenile Japanese flounder against fish pathogens. Fisheries Science 68: 1004-1011.

12. Vine NG, Leukes WD, Kaiser H (2004). In vitro growth characteristics of five candidate aquaculture probiotics and two fish pathogens grown in fish intestinal mucus. FEMS Microbiology Letters 231:145-152.

13. Olsson JC, Jöborn A, Westerdahl A, Blomberg L, Kjelleberg S, Conway PL (1998). Survival, persistence and proliferation of Vibrio anguillarum in juvenile turbot, Scophthalmus maximus L.), intestine and faeces. Journal of Fish Disease 21: 1-9.

14. Thompson FL, Thompson CC, Hoste B, Vandemeulebroecke K, Gullian M, Swings J (2003). Vibrio fortis sp. nov. and Vibrio hepatarius sp. nov., isolated from aquatic animals and the marine environment. International Journal of Systematic and Evolutionary Microbiology 53: 1495-1501. 